SLAVES TO FASHION 

एक्ष

\title{
Slaves to Fashion
}

\section{BLACK DANDYISM AND THE STYLING \\ OF BLACK DIASPORIC IDENTITY}

\author{
MONICA L. MILLER
}

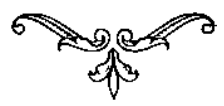

Duke University Press Durham \& London 2009 


\section{(C) 2009 Duke University Press}

$$
\text { All rights reserved }
$$

Printed in the United States of America on acid-free paper @

Designed by C. H. Westmoreland

Typeset in Whitman by Tseng Information Systems, Inc.

Library of Congress Cataloging-in-Publication Data appear on the last printed page of this book. 


\section{6⿻一𠃋}

For Carl, min älskling 



\section{@oe}

A body of people came down the platform, some of them Negroes. Yes, I thought, what about those of us who shoot up from the South into the busy city like wild jacks-in-the-box broken loose from our springs - so sudden that our gait comes like that of deep-sea divers suffering from the bends? What about those fellows waiting still and silent there on the platform, so still and silent they clash with the crowd in their very immobility, standing noisy in their very silence; harsh as a cry of terror in their quietness? What about those three boys, coming now along the platform, tall and slender, walking stiffly with swinging shoulders in their well-pressed, too-hot-for-summer suits, their collars high and tight about their necks, their identical hats of black cheap felt set upon the crowns of their heads with a severe formality above their conked hair? It was as though I'd never seen their like before: Walking slowly, their shoulders swaying, their legs swinging from their hips in trousers that ballooned upward from cuffs fitting snug about their ankles; their coats long and hip-tight with shoulders far too broad to be those of natural Western men. These fellows whose bodies seemed - what had one of my teachers said of me- "You're like one of these African sculptures, distorted in the interest of a design." Well, what design and whose?

RALPH ELLISON, Invisible Man (1952) 
